\title{
A Numerical Formula for General Prediction of Interface Bonding between Alumina and Aluminum-Containing Alloys
}

\author{
Michiko Yoshitake, ${ }^{1}$ Shinjiro Yagyu, ${ }^{1}$ and Toyohiro Chikyow ${ }^{2}$ \\ ${ }^{1}$ National Institute for Materials Science, 3-13 Sakura, Tsukuba 305-0003, Japan \\ ${ }^{2}$ National Institute for Materials Science, 1-1 Namiki, Tsukuba 305-0044, Japan \\ Correspondence should be addressed to Michiko Yoshitake; yoshitake.michiko@nims.go.jp
}

Received 19 June 2014; Accepted 9 November 2014; Published 24 December 2014

Academic Editor: Dina V. Dudina

Copyright ( $\odot 2014$ Michiko Yoshitake et al. This is an open access article distributed under the Creative Commons Attribution License, which permits unrestricted use, distribution, and reproduction in any medium, provided the original work is properly cited.

Interface termination between alumina and aluminum-containing alloys is discussed from a viewpoint of thermodynamics by extending the authors' previous discussion on the interface termination between alumina and pure metal. A numerical formula to predict interface bonding at alumina-aluminum-containing alloys is proposed. The effectiveness of the formula is examined by extracting information on interface termination from experimental results and first-principle calculations in references. It is revealed that the prediction by the formula agrees quite well with the results reported in the references. According to the formula, a terminating species can be switched from oxygen to aluminum, which had been actually demonstrated experimentally. The formula uses only basic quantities of pure elements and the formation enthalpy of oxides. Therefore it can be applied for most of aluminumcontaining alloys in the periodic table and is useful for material screening in developing interfaces with particular functions.

\section{Introduction}

Interface bonding between oxides and metals is one of the crucial factors that determine properties of materials such as bonding strength, Schottky barrier height, sensitivity of sensors, catalytic activity, and overpotential in batteries. Metal oxides, which are composed of metals and oxygen, can have differently terminated surfaces, for example, the topmost surface being occupied only by oxygen atoms or by the metal atoms that compose the oxide. When such differently terminated surfaces form the interface with metals, bonding strength and wetting properties at the interfaces depend on surface termination species [1-5]. Electron energy level alignment between the Fermi level and oxides' valence bands (band alignment) also varies largely with surface terminating species [6-10]. Regarding alumina/metal interface, which is one of the most extensively studied systems among various oxide/metal interfaces, we have studied the thermodynamics of interface termination and proposed a numerical formula to predict a terminating species at the interface [11]. A software program that gives predicted results according to the formula has been released [12].

Under conditions where a stable interface termination is determined by a metal in contact, alloying (mixing two or more metals) is one of the most frequently used techniques for modifying interfaces, especially for electric device applications where an electrode metal works only as an electronic conductor but is not chemically functioning. Because the choice of oxides is based on specific properties of the oxides, modification should be made on electrode metals, not on oxides. In this paper, therefore, the discussion on the thermodynamics of interface termination in [11] is extended to the interface between alumina and alloys that contain aluminum, and then a numerical formula for predicting a stable interface terminating species at alumina/aluminum-containing alloy interfaces is proposed. 
This work aims to offer a new tool for predicting whether alloying with aluminum is effective or not for interface modification so that time-consuming trials and errors on each system would not be necessary. We believe that the formula proposed in this work would be of great use in material development.

\section{Formula for Prediction}

2.1. Varieties in Termination. The most stable phase of alumina is alpha, which has a corundum structure with hexagonal symmetry. The planes parallel to the $c$-axis $(c$ plane) have differently terminated surfaces and could be $\mathrm{O}$ terminated, Al-terminated, or Al-double-layer-terminated. Because experiments on the $c$-plane have been mostly conducted using metal/alumina interfaces for both solidstate bonding and film growth experiments, the $c$-plane is considered in this study. Therefore, the interface bonding species can be either $\mathrm{Al}$ (M-Al-alumina, including Al-double layer) or $\mathrm{O}$ (M-O-alumina) when an interface is formed with a metal (M).

The interface between pure metal (M) and alumina will be terminated by either (1) M-Al-alumina (Al-termination) or (2) M-O-alumina (O-termination). Here, the influence of the coverage is neglected as discussed in the previous paper [11]. When the discussion is extended to the interface with aluminum-containing alloy (MAl), $\mathrm{M}$ - $\mathrm{Al}^{\prime}$-alumina (Altermination, $\mathrm{Al}^{\prime}$ denotes terminating $\mathrm{Al}$ ) in pure $\mathrm{M}$ system is replaced by $(\mathrm{MAl})-\mathrm{Al}^{\prime}$-alumina, where the atom that binds to $\mathrm{Al}^{\prime}$ can be either $\mathrm{M}^{*}$ or $\mathrm{Al}^{*}$ in $\mathrm{MAl}$ (here, $\mathrm{M}^{*}$ and $\mathrm{Al}^{*}$ denote atoms from alloys). Likewise, $\mathrm{M}-\mathrm{O}^{\prime}$-alumina (O-termination, $\mathrm{O}^{\prime}$ denotes terminating $\mathrm{O}$ ) is replaced by (MAl)$\mathrm{O}^{\prime}$-alumina, where the atom that binds to $\mathrm{O}^{\prime}$ can be either $\mathrm{M}^{*}$ or $\mathrm{Al}^{*}$ in $\mathrm{MAl}$. Then, there would be four different types of termination at the interface:

(alloy) | interface | alumina
(A) $(\mathrm{MAl})-\mathrm{M}^{*}-\mathrm{Al}-$ alumina
(Al-termination)
(B) $(\mathrm{MAl})-\underline{\mathrm{Al}^{*}-\mathrm{Al}}$-alumina
(Al-termination)
(C) $(\mathrm{MAl})-\mathrm{M}^{*}-\mathrm{O}-$ alumina
(O-termination)
(D) $(\mathrm{MAl})-\mathrm{Al}^{*}-\mathrm{O}-$ alumina

Although (D) is initially derived from the O-terminated interface between (MAl) alloy and alumina, it can be regarded as Al-termination because this is the same as either (A) or (B).

2.2. Procedure for Prediction. Thermodynamic equilibrium among the four types of termination (A)-(D) has been considered. The equilibrium is determined by Gibbs energy difference among the terminations [11]. In our previous paper on the interface between alumina and pure metal, we use M$\mathrm{Al}$ and $\mathrm{M}-\mathrm{O}$ bonding energy to obtain Gibbs energy difference among different terminations for simplicity [11]. Here, for the interface between alumina and aluminum-containing alloy (MAl), we use $\mathrm{M}-\mathrm{Al}, \mathrm{Al}-\mathrm{Al}, \mathrm{M}-\mathrm{O}$, and $\mathrm{Al}-\mathrm{O}$ bonding energy.

As in the previous paper, $\mathrm{M}-\mathrm{Al}$ bonding energy is estimated either by the adsorption energy of Al on M (Approx1) or by subtracting the adsorption energy of $M$ on $M$ from that of $\mathrm{Al}$ on $\mathrm{M}$ (Approx-2). The subtraction is considered because the values of adsorption energy include not only the influence of chemical interaction between $\mathrm{Al}$ and $\mathrm{M}$ but also that of cohesion energy. $\mathrm{M}-\mathrm{O}$ bonding energy is estimated either by the adsorption energy of oxygen on M (Approx-1) or by subtracting the dissociation energy of molecular oxygen from the adsorption energy of oxygen on M (Approx-2). The reason of adopting adsorption energy of metals to estimate $\mathrm{M}-\mathrm{Al}$ or $\mathrm{Al}-\mathrm{Al}$ bonding energy and that of oxygen for $\mathrm{M}-\mathrm{O}$ bonding energy is as follows: values of formation enthalpy of oxides and intermetallic compounds or of mixing enthalpy include terms not only from chemical interaction but also from structural change. At the interface structural relaxation occurs more easily than in bulk and the structural term would be smaller and can be neglected for rough estimation.

The adsorption energy of $\mathrm{Al}$ on $\mathrm{M}(=\mathrm{Al}$ on $\mathrm{Al}$ when $\mathrm{M}=$ $\mathrm{Al}$ ) and $\mathrm{M}$ on $\mathrm{M}$ were calculated using (1), which is based on Meadima's formula [13]:

$$
\begin{aligned}
\Delta H_{\mathrm{ad}}(A \text { on } B)= & -F \times \gamma_{B} \times S_{A}+(1-F) \times \gamma_{A} \times S_{A} \\
& +F \times \Delta H_{\text {sol }}(A \text { in } B)-\Delta H_{\text {vap }}(A),
\end{aligned}
$$

where $\Delta H_{\mathrm{ad}}(A$ on $B)$ is the adsorption energy of $A$ on $B, \gamma_{A}$, and $S_{A}$, and $\gamma_{B}$ and $S_{B}$ are surface energy and surface area of $A$ and $B$, respectively. $\Delta H_{\text {sol }}(A$ in $B)$ is the heat of mixing of $A$ in $B ; \Delta H_{\text {vap }}$ is vaporization enthalpy. $F$ is the portion of the area of $A$ in contact with $B$, which is typically around 0.4. Here, the energy is described per mol. $\Delta H_{\text {sol }}(A$ in $B)$ is calculated by the following equation:

$$
\begin{aligned}
\Delta H_{\text {sol }}(A \text { in } B)= & 2 V(A)^{2 / 3} \times\left(n(A)^{-1 / 3}+n(B)^{-1 / 3}\right)^{-1} \times N_{0} \\
& \times P \times\left\{-e(\Delta \phi)^{2}+\frac{Q}{P\left(\Delta n^{1 / 3}\right)^{2}}-\frac{R}{P}\right\},
\end{aligned}
$$

where $V(A)$ is the molar volume of metal $A, n(A)$, and $n(B)$ are the electron density of $A$ and $B$ at the boundary of the Wigner-Seitz cell, $\Delta \phi$ is the work function difference between $A$ and $B$, and $P, Q$, and $R$ are parameters. $N_{0}$ is the Avogadro's number. The detail of the calculation and values for $\gamma_{A}$ and $\gamma_{B}, \Delta H_{\text {vap }}, V(A), n(A)$, and $n(B), \Delta \phi$, and three parameters $P, Q$, and $R$ are described in [14]. The values of the calculated adsorption energy for each $\mathrm{M}-\mathrm{Al}$ combination were obtained using the software [15] released by one of the authors and listed in Table 1.

The adsorption energy of oxygen on $M$ is estimated in the following way. It has been reported [16] that the initial heat of adsorption of oxygen on some metals [17] has linear dependence on the standard enthalpy of formation [18] of the corresponding oxides with the highest oxidation state. The values of the formation enthalpy and the valence of the corresponding oxides were reexamined using other references $[19,20]$. We decided to use the values from [20] to correlate the initial heat of adsorption of oxygen (Hads) with the formation enthalpy of the corresponding oxide with the highest oxidation state (Hform) except Cr. The following 
TABLE 1: Adsorption energy of $\mathrm{Al}$ and other metals ( $\mathrm{M}$ ) on $\mathrm{M}$ and their subtracted values.

\begin{tabular}{|c|c|c|c|}
\hline $\begin{array}{l}\text { Metal- } \\
\text { M }\end{array}$ & $\begin{array}{c}\text { Al on } \mathrm{M} \\
\text { Adsorption } \\
\text { energy }(\mathrm{kJ} / \mathrm{mol})\end{array}$ & $\begin{array}{c}\text { M on M } \\
\text { Adsorption } \\
\text { energy }(\mathrm{kJ} / \mathrm{mol})\end{array}$ & $\begin{array}{c}(\mathrm{Al} \text { on } \mathrm{M})-(\mathrm{M} \text { on } \\
\mathrm{M}) \\
\text { Energy difference } \\
(\mathrm{kJ} / \mathrm{mol})\end{array}$ \\
\hline $\mathrm{Al}$ & 270 & 270 & 0 \\
\hline $\mathrm{Si}$ & 277 & 359 & -82 \\
\hline $\mathrm{Ti}$ & 384 & 363 & 21 \\
\hline V & 400 & 401 & -1 \\
\hline $\mathrm{Cr}$ & 377 & 303 & 74 \\
\hline $\mathrm{Fe}$ & 392 & 316 & 76 \\
\hline $\mathrm{CO}$ & 408 & 335 & 73 \\
\hline $\mathrm{Ni}$ & 407 & 340 & 67 \\
\hline $\mathrm{Cu}$ & 332 & 265 & 67 \\
\hline $\mathrm{Zn}$ & 299 & 113 & 186 \\
\hline $\mathrm{Ga}$ & 243 & 227 & 16 \\
\hline $\mathrm{Ge}$ & 258 & 297 & -39 \\
\hline $\mathrm{Zr}$ & 389 & 490 & -101 \\
\hline $\mathrm{Nb}$ & 409 & 582 & -173 \\
\hline Mo & 410 & 523 & -113 \\
\hline $\mathrm{Ru}$ & 454 & 521 & -67 \\
\hline $\mathrm{Rh}$ & 447 & 435 & 12 \\
\hline $\mathrm{Pd}$ & 413 & 283 & 130 \\
\hline $\mathrm{Ag}$ & 280 & 222 & 58 \\
\hline In & 228 & 198 & 30 \\
\hline Sn & 230 & 254 & -24 \\
\hline $\mathrm{La}$ & 312 & 358 & -46 \\
\hline $\mathrm{Hf}$ & 399 & 492 & -93 \\
\hline $\mathrm{Ta}$ & 433 & 627 & -194 \\
\hline $\mathrm{W}$ & 434 & 695 & -261 \\
\hline $\operatorname{Re}$ & 496 & 612 & -116 \\
\hline Os & 487 & 636 & -149 \\
\hline Ir & 474 & 535 & -61 \\
\hline $\mathrm{Pt}$ & 450 & 448 & 2 \\
\hline $\mathrm{Au}$ & 325 & 293 & 32 \\
\hline $\mathrm{Hg}$ & 262 & 60 & 202 \\
\hline $\mathrm{Pb}$ & 215 & 153 & 62 \\
\hline $\mathrm{Bi}$ & 211 & 169 & 42 \\
\hline
\end{tabular}

numerical relationship has been obtained with the correlation coefficient of 0.977 :

$$
\begin{aligned}
\text { Hads }(\mathrm{kJ} / \mathrm{mol}-\mathrm{O})= & 0.719 \times \text { Hform }(\mathrm{kJ} / \mathrm{mol}-\mathrm{M}) \\
& +230(\mathrm{~kJ} / \mathrm{mol}-\mathrm{O}) .
\end{aligned}
$$

We use values of Hads calculated by (3) as the adsorption energy of oxygen on $\mathrm{M}$.

In Table 2, formation enthalpy of various oxides to be used for the calculation (after [20] except those in italics which are from [19]) and the calculated adsorption energy values are listed. For readers' convenience, values for metals that were not reported in references we discuss later are also given.

In the previous paper, the following two expressions were used in order to predict whether the interface termination is either $\mathrm{M}$-Al-alumina or $\mathrm{M}-\mathrm{O}$-alumina between pure metal and alumina.

Approx-1 is

$$
\text { (AlonM) - (OonM) . }
$$

Approx-2 is

$$
\begin{aligned}
\{(\text { Alon } M)-(\text { MonM })\}-\{ & (\text { OonM }) \\
& \left.-\frac{1}{2}\left(\mathrm{O}_{2} \text { dissociation energy }\right)\right\},
\end{aligned}
$$

where $\mathrm{O}_{2}$ dissociation energy $=493.07 \mathrm{~kJ} / \mathrm{mol}[21]$. Approx2 has been proposed because the value of (AlonM) includes both chemical interaction between $\mathrm{Al}$ and $\mathrm{M}$ and cohesive energy of atomic $\mathrm{Al}$, and therefore, in order to extract the term caused by only chemical interaction, subtraction of cohesive energy is necessary. The situation is the same for (OonM), where both chemical interaction between $\mathrm{O}$ and $\mathrm{M}$ and cohesive energy of atomic $\mathrm{O}$ are included and the subtraction of cohesive energy (=the half of $\mathrm{O}_{2}$ dissociation energy) is needed. Prediction with Approx-1 is that if (4) is positive, that is, (AlonM) $>(\mathrm{OonM}), \mathrm{M}-\mathrm{Al}$ bonding is preferred to $\mathrm{M}-\mathrm{O}$ bonding and if $(\mathrm{AlonM})<(\mathrm{OonM}), \mathrm{M}-$ $\mathrm{O}$ bonding is preferred. With Approx-2, prediction goes as follows: if (5) is positive, that is, $\{($ AlonM $)-($ MonM $)\}>$ $\left\{(\mathrm{OonM})-1 / 2\left(\mathrm{O}_{2}\right.\right.$ dissociation energy $\left.)\right\}, \mathrm{M}-\mathrm{Al}$ bonding is preferred, and vice versa.

Four types of terminations (A)-(D) for aluminumcontaining alloy, as described in Section 2.1, are derived from either $\mathrm{M}$-Al-alumina or $\mathrm{M}-\mathrm{O}$-alumina interface in pure metal, where (A) and (B) are derived from $\mathrm{M}-\mathrm{Al}$ alumina and (C) and (D) are derived from $\mathrm{M}-\mathrm{O}$-alumina. Therefore, in order to predict which one of terminations is realized at the interface with aluminum-containing alloy, we first predict whether $\mathrm{M}-\mathrm{Al}$-alumina or $\mathrm{M}-\mathrm{O}$-alumina is realized at the interface without aluminum in the alloy using either Approx-1 or Approx-2. Once $\mathrm{M}-\mathrm{Al}$-alumina is predicted, the second step is to predict whether the interface is (A) or (B) at the interface with aluminum-containing alloy. When $\mathrm{M}-\mathrm{O}$-alumina is predicted, the second step is to predict whether the interface is $(\mathrm{C})$ or $(\mathrm{D})$. Whether $(\mathrm{A})$ or (B) is realized is determined by comparing the value of (AlonAl) with that of (AlonM). If (AlonAl) $>$ (AlonM), $\mathrm{Al}-\mathrm{Al}$ bonding is preferred to $\mathrm{M}-\mathrm{Al}$ bonding and the termination becomes (B). Similarly, (C) or (D) is determined by the value of (OonAl) with respect to (OonM). Here, the value of $(\mathrm{OonAl})$ is obtained by calculating $(\mathrm{OonM})$ with $\mathrm{M}=\mathrm{Al}$ and is $833.06 \mathrm{~kJ} / \mathrm{mol}$. If $(\mathrm{OonAl})>(\mathrm{OonM}), \mathrm{Al}-\mathrm{O}$ bonding is preferred to $\mathrm{M}-\mathrm{O}$ bonding and the termination becomes (D), which is regarded as Al-termination. Here, comparison between (AlonAl) and (AlonM) or between (OonAl) and (OonM) does not need subtraction like in (5), because the 
TABLE 2: Values of oxide formation enthalpy and calculated adsorption energy of oxygen on various metals (M) and related values.

\begin{tabular}{|c|c|c|c|c|c|c|}
\hline & & $\mathrm{kJ} / \mathrm{mol}$ & $\mathrm{kJ} / \mathrm{mol}-\mathrm{M}$ & $\mathrm{kJ} / \mathrm{mol}-\mathrm{O}$ & $\mathrm{kJ} / \mathrm{mol}-\mathrm{O}$ & Energy difference $(\mathrm{kJ} / \mathrm{mol})$ \\
\hline $\mathrm{Mg}$ & $\mathrm{MgO}$ & 601.6 & 601.6 & 601.6 & 664.14 & 419.61 \\
\hline $\mathrm{Al}$ & $\mathrm{Al}_{2} \mathrm{O}_{3}$ & 1675.7 & 837.85 & 558.5667 & 833.06 & 588.53 \\
\hline $\mathrm{Si}$ & $\mathrm{SiO}_{2}$ & 910.7 & 910.7 & 455.35 & 885.15 & 640.62 \\
\hline $\mathrm{Ti}$ & $\mathrm{TiO}_{2}$ & 944 & 944 & 472 & 908.96 & 664.43 \\
\hline $\mathrm{V}$ & $\mathrm{V}_{2} \mathrm{O}_{5}$ & 1550.6 & 775.3 & 310.12 & 788.34 & 543.81 \\
\hline $\mathrm{Cr}$ & $\mathrm{Cr}_{2} \mathrm{O}_{3}$ & 1139.7 & 569.85 & 379.9 & 641.44 & 396.91 \\
\hline $\mathrm{Mn}$ & $\mathrm{MnO}_{2}$ & 520 & 520 & 260 & 605.80 & 361.27 \\
\hline $\mathrm{Fe}$ & $\mathrm{Fe}_{2} \mathrm{O}_{3}$ & 824.2 & 412.1 & 274.7333 & 528.65 & 284.12 \\
\hline $\mathrm{CO}$ & $\mathrm{CO}_{3} \mathrm{O}_{4}$ & 891 & 297 & 222.75 & 446.36 & 201.83 \\
\hline $\mathrm{Ni}$ & $\mathrm{Ni}_{2} \mathrm{O}_{3}$ & 489.5 & 244.75 & 163.1667 & 409.00 & 164.47 \\
\hline $\mathrm{Cu}$ & $\mathrm{CuO}$ & 157.3 & 157.3 & 157.3 & 346.47 & 101.94 \\
\hline $\mathrm{Zn}$ & $\mathrm{ZnO}$ & 350.5 & 350.5 & 350.5 & 484.61 & 240.08 \\
\hline $\mathrm{Ga}$ & $\mathrm{Ga}_{2} \mathrm{O}_{3}$ & 1089.1 & 544.55 & 363.0333 & 623.35 & 378.82 \\
\hline $\mathrm{Ge}$ & $\mathrm{GeO}_{2}$ & 580 & 580 & 290 & 648.70 & 404.17 \\
\hline $\mathrm{Zr}$ & $\mathrm{ZrO}_{2}$ & 1094.3 & 1094.324 & 547.162 & 1016.44 & 771.91 \\
\hline $\mathrm{Nb}$ & $\mathrm{Nb}_{2} \mathrm{O}_{5}$ & 1899.5 & 949.75 & 379.9 & 913.07 & 668.54 \\
\hline Mo & $\mathrm{MoO}_{3}$ & 745.1 & 745.1 & 248.3667 & 766.75 & 522.22 \\
\hline $\mathrm{Ru}$ & $\mathrm{RuO}_{4}$ & 239.3 & 239.3 & 59.825 & 405.10 & 160.57 \\
\hline $\mathrm{Rh}$ & $\mathrm{Rh}_{2} \mathrm{O}_{3}$ & 343.0 & 171.5 & 114.3333 & 356.62 & 112.09 \\
\hline $\mathrm{Pd}$ & $\mathrm{PdO}$ & 85.4 & 85.4 & 85.4 & 295.06 & 50.53 \\
\hline $\mathrm{Ag}$ & $\mathrm{Ag}_{2} \mathrm{O}_{2}$ & 24.3 & 12.15 & 12.15 & 242.69 & -1.84 \\
\hline In & $\mathrm{In}_{2} \mathrm{O}_{3}$ & 925.8 & 462.9 & 308.6 & 564.97 & 320.44 \\
\hline Sn & $\mathrm{SnO}_{2}$ & 577.63 & 577.63 & 288.815 & 647.01 & 402.48 \\
\hline $\mathrm{La}$ & $\mathrm{La}_{2} \mathrm{O}_{3}$ & 1793.7 & 896.85 & 597.9 & 875.25 & 630.72 \\
\hline Hf & $\mathrm{HfO}_{2}$ & 1144.7 & 1144.7 & 572.35 & 1052.46 & 807.93 \\
\hline $\mathrm{Ta}$ & $\mathrm{Ta}_{2} \mathrm{O}_{5}$ & 2046 & 1023 & 409.2 & 965.45 & 720.92 \\
\hline W & $\mathrm{WO}_{3}$ & 842.9 & 842.9 & 280.9667 & 836.67 & 592.14 \\
\hline $\operatorname{Re}$ & $\mathrm{Re}_{2} \mathrm{O}_{7}$ & 1240.1 & 620.05 & 177.1571 & 677.34 & 432.81 \\
\hline Os & $\mathrm{OsO}_{4}$ & 391.248 & 391.248 & 97.812 & 513.74 & 269.21 \\
\hline Ir & $\mathrm{IrO}_{2}$ & 274.1 & 274.1 & 137.05 & 429.98 & 185.45 \\
\hline $\mathrm{Pt}$ & $\mathrm{PtO}_{2}$ & 133.3 & 133.3 & 66.65 & 329.31 & 84.78 \\
\hline $\mathrm{Au}$ & $\mathrm{AuO}_{x}$ & $<0$ & $<0$ & $<0$ & $<0$ & $<0$ \\
\hline $\mathrm{Hg}$ & $\mathrm{HgO}$ & 90.79 & 90.79 & 90.79 & 298.91 & 54.38 \\
\hline $\mathrm{Pb}$ & $\mathrm{PbO}$ & 218 & 218 & 218 & 389.87 & 145.34 \\
\hline $\mathrm{Bi}$ & $\mathrm{Bi}_{2} \mathrm{O}_{3}$ & 573.9 & 191.3 & 286.95 & 370.78 & 126.25 \\
\hline
\end{tabular}

cohesive energy is canceled when (AlonAl) and (AlonM) are compared $[($ Alon $\mathrm{Al})-($ AlonM $)=\{(\mathrm{AlonAl})-($ Alon $\mathrm{Al})\}-$ $\{($ AlonM $)-($ AlonAl $)\}]$, as well as for (OonAl) and (OonM) $\left[(\right.$ Oon $\mathrm{Al})-(\mathrm{OonM})=\left\{(\mathrm{Oon} \mathrm{Al})-1 / 2\left(\mathrm{O}_{2}\right.\right.$ dissociation energy $)\}-\left\{(\mathrm{OonM})-1 / 2\left(\mathrm{O}_{2}\right.\right.$ dissociation energy $\left.\left.)\right\}\right]$. Therefore, the expressions for each termination for aluminumcontaining alloy (Approx-1) are as follows, where the flow chart for finding an expression is shown in Figure 1(a):
(a) $($ OonM $)<($ AlonM $)>($ AlonAl $)$
(b) $($ OonM $)<($ AlonM $)<($ AlonAl $)$
(c) $($ OonAl $)<($ OonM $)>($ AlonM $)$
(d) $($ Oon $\mathrm{Al})>($ OonM $)>($ AlonM $)$

When Approx-2 is used in the first step to predict whether $\mathrm{M}-\mathrm{Al}$-alumina or $\mathrm{M}-\mathrm{O}$-alumina is realized at the interface without aluminum in the alloy, the comparison between (OonM) and (AlonM) should be made by replacing (OonM) by $\left\{(\mathrm{OonM})-1 / 2\left(\mathrm{O}_{2}\right.\right.$ dissociation energy $\left.)\right\}$ and (AlonM) by $\{($ AlonM $)-($ MonM $)\}$. Then the corresponding expressions to (a)-(d) become as follows, where the flow chart for finding an expression is shown in Figure 1(b):

$\left(\mathrm{a}^{\prime}\right)(\mathrm{OonM})-1 / 2\left(\mathrm{O}_{2}\right.$ dissociation energy $)<($ AlonM $)-$ $(\mathrm{MonM})>($ Alon $\mathrm{Al})-(\mathrm{MonM})$

$\left(b^{\prime}\right)($ OonM $)-1 / 2\left(\mathrm{O}_{2}\right.$ dissociation energy $)<($ AlonM $)-$ $($ MonM $)<($ AlonAl $)-($ MonM $)$

$\left(c^{\prime}\right)($ Oon $\mathrm{Al})-1 / 2\left(\mathrm{O}_{2}\right.$ dissociation energy $)<($ OonM $)-$ $1 / 2\left(\mathrm{O}_{2}\right.$ dissociation energy $)>($ AlonM $)-($ MonM $)$

$\left(\mathrm{d}^{\prime}\right)(\mathrm{Oon} \mathrm{Al})-1 / 2\left(\mathrm{O}_{2}\right.$ dissociation energy $)>($ OonM $)-$ $1 / 2\left(\mathrm{O}_{2}\right.$ dissociation energy $)>($ Alon $M)-($ MonM $)$. 


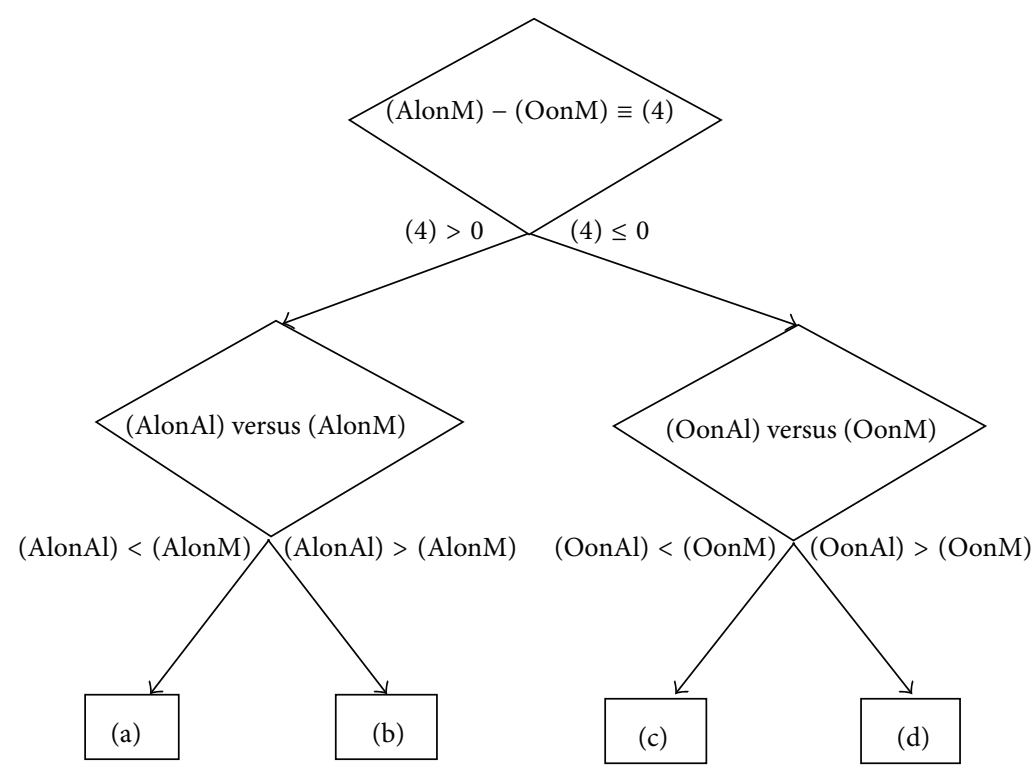

(a) Approx-1

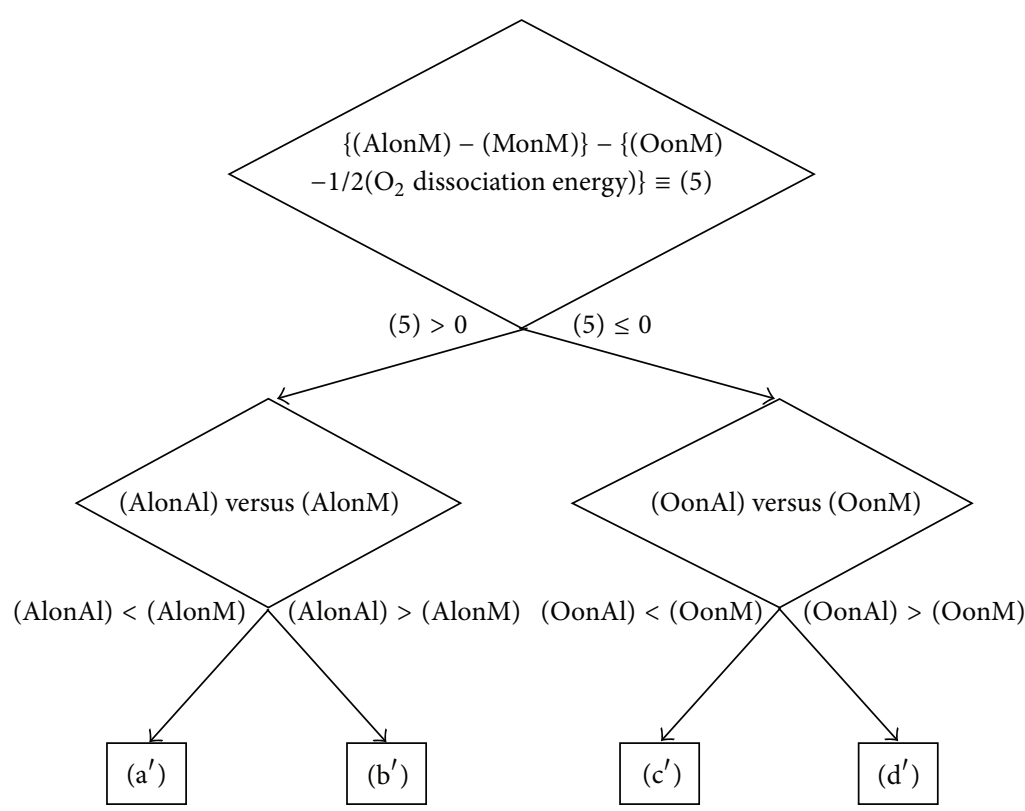

(b) Approx-2

FIGURE 1: Flow chart for finding an expression that predicts termination.

If $(d)$ or $\left(d^{\prime}\right)$ is satisfied, the interface between alumina and pure metal $\mathrm{M}$ is $\mathrm{O}$-terminated, whereas the interface with $\mathrm{M}$ alloyed with $\mathrm{Al}$ is $\mathrm{Al}$-terminated. This is the key to switch interface termination species from oxygen to aluminum by adding $\mathrm{Al}$ to metals that satisfy $(\mathrm{d})$ or $\left(\mathrm{d}^{\prime}\right)$. Whether this switching of interface termination species occurs or not is governed by the adsorption energy of oxygen on $M$ and Al. As in the expressions (d) and ( $\left.\mathrm{d}^{\prime}\right)$, when the adsorption energy of oxygen on $\mathrm{Al}$ is larger than that on $\mathrm{M}, \mathrm{Al}-\mathrm{O}$ bonding is preferred at the interface and type (D) termination, that is, Al-termination, is formed. On the other hand, it is clear that switching Al-terminated interface to O-terminated one by alloying with $\mathrm{Al}$ is impossible from the expressions (a)-(d). It should be noted that the systems where different termination is predicted in the first step using by either Approx-1 or Approx-2 are limited only to $\mathrm{Ru}, \mathrm{Rh}, \mathrm{Ir}, \mathrm{Pt}$, and $\mathrm{Hg}$ (predictions for these systems are $\mathrm{M}-\mathrm{Al}$-alumina with Approx-1 and M-O-alumina with Approx-2). Furthermore, aluminumcontaining alloys of these metals are predicted to be Alterminated whether interface termination is predicted as $\mathrm{M}-$ Al-alumina or $\mathrm{M}-\mathrm{O}$-alumina in the first step (termination (A) or (D)). Therefore, we may be able to use Approx-1 in the first step for predicting the interface in aluminum-containing alloy. 
TABLE 3: Binding energies of $\mathrm{Al} 2 \mathrm{p}$ in $\mathrm{Ti}-\mathrm{Al}$ compounds prepared in various conditions compared to those in alumina on Cu and Ni related metals as references.

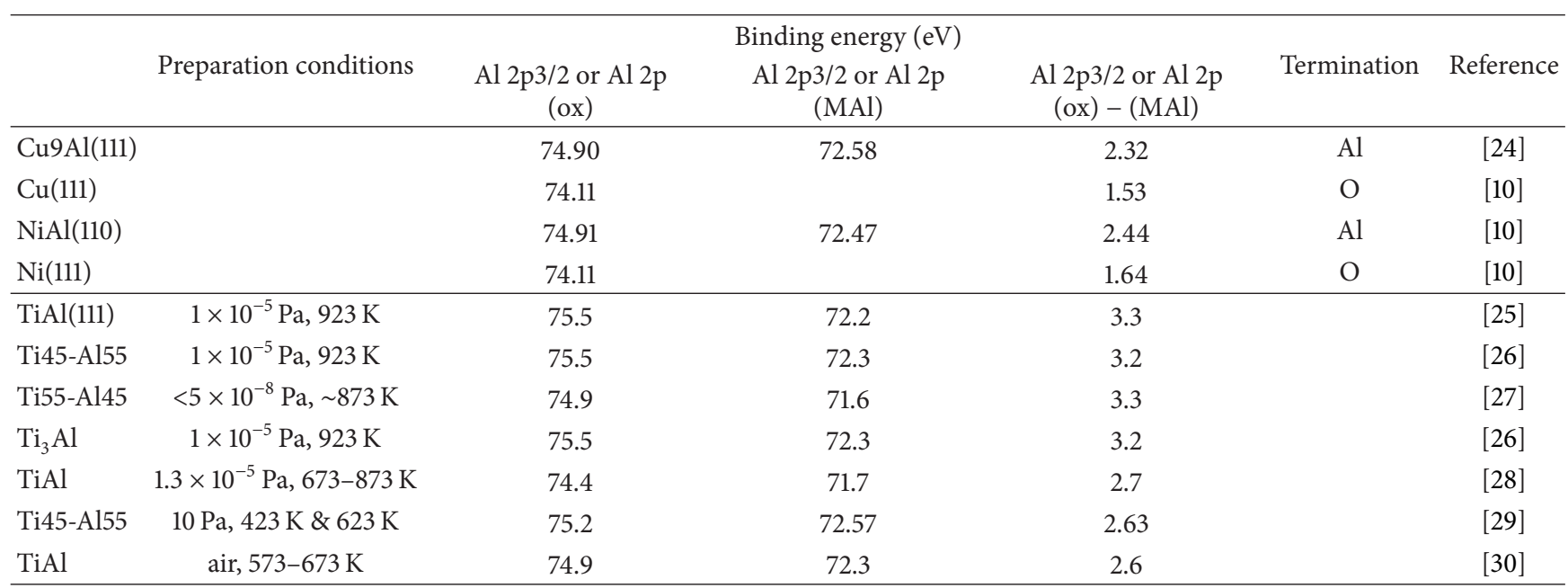

In summary, to find a type of interface bonding in aluminum-containing alloy (MAl), interface termination at alumina-corresponding pure metal (without aluminum in the alloy) should be first examined. Then, if the interface with pure metal is Al-terminated, values of (AlonM) and (AlonAl) are to be compared. For O-terminated interface with pure metal, values of (OonM) and (Oon $\mathrm{Al})$ should be compared. This procedure gives the type of interface bonding in aluminum-containing alloy from expressions (A)-(D). After looking for $M$ that satisfies (AlonAl) $>$ (AlonM) $(M=G a$, $\mathrm{Ge}, \mathrm{In}, \mathrm{Sn}, \mathrm{Hg}, \mathrm{Pb}, \mathrm{Bi}$ in Table 1), we found that there is no $\mathrm{M}$ with $(\mathrm{Oon} M)<($ Alon $M)$. Therefore, there is no $\mathrm{M}$ that satisfies expression (B).

It should be noted that the values of (OonM) are derived from the standard formation enthalpy of corresponding oxide, which is defined at 1 bar pressure. Because both oxidation and reduction of metal can occur in the same system at different oxygen pressure, a terminating species would vary with oxygen pressure, especially for metals with relatively small standard formation enthalpy values.

There is one more thing to be noted. In all the above discussion, the possibility of alumina reduction is excluded. However, if the oxide formation enthalpy of metal M per mol$\mathrm{O}$ is larger than that of alumina, formation of oxide with $\mathrm{M}$ and reduction of alumina should occur, which is expected for $\mathrm{M}=\mathrm{La}, \mathrm{Hf}$ in Table 2.

\section{Termination in Aluminum-Containing Alloys in References}

3.1. Experimental Results. There are only a limited number of references that handle interface termination between alumina and aluminum-containing alloys. We have investigated interface termination using $\mathrm{NiAl}(110)$ and $\mathrm{Cu}-9 \mathrm{Al}(111)$ [10] and showed that $\mathrm{Al} 2 \mathrm{p}$ XPS peak is a good measure to judge a type of termination. If $\mathrm{Al} 2 \mathrm{p}$ peak has a component between that for $\mathrm{Al}_{2} \mathrm{O}_{3}$ and metallic $\mathrm{Al}$, the component is attributed to the interface and the interface is Al-terminated. For $\mathrm{NiAl}(110)$, the shoulder in $\mathrm{Al} 2 \mathrm{p}$ peak in oxidized substrate has been known [22], which were attributed to $\mathrm{Al}$ that binds the substrate and alumina film using calculation and STM [23].

Although other references did not discuss interface termination, by examining the reported Al 2p XPS spectra, a type of interface termination can be estimated in the above way. For $\mathrm{FeAl}$, a similar shoulder in $\mathrm{Al} 2 \mathrm{p}$ peak as in $\mathrm{NiAl}$ and $\mathrm{Cu}-9 \mathrm{Al}$ was reported [31], which indicates that the interface between $\mathrm{FeAl}$ and alumina formed by the oxidation of $\mathrm{FeAl}$ was Al-terminated though the authors of the paper did not mention it. In addition to $\mathrm{NiAl}(110)$, when $\mathrm{NiAl}(111)$, a different orientation of the same intermetallic, was oxidized, a similar shoulder in $\mathrm{Al} \mathrm{2p}$ was reported [32].

There are XPS studies on the oxidation of TiAl and $\mathrm{Ti}_{3} \mathrm{Al}$, but well resolved $\mathrm{Al} 2 \mathrm{p}$ spectra were not reported. However, we are able to estimate the interface termination difference by examining the reported $\mathrm{Al} 2 \mathrm{p}$ binding energies in the following way. In Table 3, Al 2p binding energy values of alumina and of intermetallics taken from references [10, 24-30] are listed. In the case of $\mathrm{Cu}$ and $\mathrm{Ni}$ systems, where all the data come from our laboratory under the same energy calibration conditions, differences of $\mathrm{Al} 2 \mathrm{p}_{3 / 2}$ values in alumina $\left(\mathrm{Al} 2 \mathrm{p}_{3 / 2}\right.$ (ox)) with respect to the ones in $\mathrm{M}-\mathrm{Al}\left(\mathrm{Al} 2 \mathrm{p}_{3 / 2}(\mathrm{MAl})\right)$ for Al-terminated samples (2.3-2.4 eV) are clearly different from those for O-terminated ones $(1.5-1.6 \mathrm{eV})$. For Ti systems, the energy difference between $\mathrm{Al} \mathrm{2p}$ (ox) and $\mathrm{Al} 2 \mathrm{p}$ (MAl) falls in two categories, one 3.2-3.3 eV and the other 2.6-2.7 (in the references, $\mathrm{Al} 2 \mathrm{p}_{3 / 2}$ and $\mathrm{Al} 2 \mathrm{p}_{1 / 2}$ were not resolved). The smaller energy difference appears to suggest $\mathrm{O}$-termination, while the larger one is for Al-termination. If we examine the preparation conditions for all these experiments in Table 3, it seems that the suggested terminating species is dependent on the oxidation potential during the interface formation. In the case of lower oxygen pressure and/or higher temperature (=lower oxidation potential), larger energy difference, that is, Al-termination, appears to be realized. The interface termination deduced from reported experiments is schematically summarized in Table 4. 
TABLE 4: Schematic representation of interface terminating species at interfaces with alumina reported in experiments.

\begin{tabular}{|c|c|c|c|c|c|c|c|c|c|c|}
\hline $\mathrm{Mg}$ & & & & & & & & & & \\
\hline $\mathrm{Ca}$ & $\mathrm{Sc}$ & $\mathrm{Ti}^{*}$ & $\mathrm{~V}^{*}$ & $\mathrm{Cr}^{*}$ & $\mathrm{Mn}$ & $\mathrm{Fe}^{*}$ & $\mathrm{CO}^{*}$ & $\mathrm{Ni}^{*}$ & $\mathrm{Cu}^{*}$ & $\mathrm{Zn}$ \\
\hline & & $\mathrm{TiAl}^{\ddagger}$ & & & & $\mathrm{FeAl}^{\dagger}$ & $\mathrm{COAl}$ & $\mathrm{NiAl}^{\dagger}$ & $\mathrm{Cu}(\mathrm{Al})^{\dagger}$ & \\
\hline $\mathrm{Sr}$ & $\mathrm{Y}$ & $\mathrm{Zr}$ & $\mathrm{Nb}^{*}$ & Mo & Tc & $\mathrm{Ru}$ & $\mathrm{Rh}$ & $\mathrm{Pd}$ & $\mathrm{Ag}^{\ddagger}$ & $\mathrm{Cd}$ \\
\hline $\mathrm{Ba}$ & $\mathrm{La}$ & $\mathrm{Hf}$ & $\mathrm{Ta}$ & $\mathrm{W}$ & $\operatorname{Re}$ & Os & Ir & $\mathrm{Pt}$ & $\mathrm{Au}$ & $\mathrm{Hg}$ \\
\hline
\end{tabular}

3.2. Theoretical Results. To the authors' knowledge, there is no reference that calculates the stability of interface termination at alumina/aluminum-containing alloy (including intermetallics) by first-principle calculations. The references that discuss the chemical potential of $\mathrm{Al}, \Delta \mu_{\mathrm{Al}}$, as a parameter in the thermodynamic study of interface termination for alumina-Ni, $\mathrm{Cu}, \mathrm{Ag}$, and $\mathrm{Au}$ [33-35] interfaces handle $\mathrm{Al}-$ containing intermetallics. Their conclusion is that an interface terminating species changes from oxygen to aluminum according to the increase of the chemical potential of $\mathrm{Al}$ in metals as schematically shown in Figure 2. This $\Delta \mu_{\mathrm{Al}}$ is a function of both oxygen partial pressure and aluminum activity $a_{\mathrm{Al}}$ in metals. The figure assumes that alumina is more stable than oxide of metal M, MO. Here, using Figure 2, we discuss the influence of aluminum activity under constant oxygen partial pressure, where alumina is stable. From the right to the left in the figure, metal composition changes from pure metal to $\mathrm{Al}$ intermetallics. On the border $\mathrm{B}$ at the right side in Figure 2, the interface is not $\mathrm{Al}_{2} \mathrm{O}_{3} / \mathrm{M}$ (pure metal) but $\mathrm{Al}_{2} \mathrm{O}_{3} / \mathrm{MO}_{x}$ (metal oxide). When $a_{\mathrm{Al}}$ is larger than that at the border $\mathrm{B}$, the interface is $\mathrm{O}$-terminated. If mixed oxide phase MAlO exists, the border $\mathrm{C}$ appears in the figure and the interface with alumina would be $\mathrm{Al}_{2} \mathrm{O}_{3} / \mathrm{MAlO}_{x}$ instead of $\mathrm{Al}_{2} \mathrm{O}_{3} / \mathrm{MO}_{x}$. The interface $\mathrm{Al}_{2} \mathrm{O}_{3} / \mathrm{MAlO}_{x}$ is regarded as $\mathrm{O}$-terminated from a bonding point of view, because $\mathrm{M}-\mathrm{O}$ bonding, not $\mathrm{M}-\mathrm{Al}$, exists at the interface. On the border $\mathrm{A}$ at the left side in Figure 2, $\mathrm{Al}_{2} \mathrm{O}_{3}$ reduces to $\mathrm{Al}$ metal that forms an intermetallic compound $\mathrm{MAl}$, such as $\mathrm{Cu}_{3} \mathrm{Al}$ and $\mathrm{Ni}_{3} \mathrm{Al}$, and the interface is $\mathrm{Al}_{2} \mathrm{O}_{3} / \mathrm{MAl}$, not $\mathrm{Al}_{2} \mathrm{O}_{3} / \mathrm{M}$. Therefore, the reference tells us that the interface between $\mathrm{MAl}(\mathrm{M}=\mathrm{Ni}, \mathrm{Cu}$, $\mathrm{Ag}$ and $\mathrm{Au}$ ) and alumina is Al-terminated.

\section{Comparison between Prediction and Results in References}

Here, we examine the prediction derived from the proposed expressions for each system and compare with the results deduced from the reported results.

In Table 5, the prediction for pure metal (M), the examination of the expression described in Section 2.2 (both Approx-1 and Approx-2), and the resulting prediction for aluminum-containing alloy $(\mathrm{MAl})$ are listed for various metals. The results from the experimental references are also shown in the table. For $\mathrm{M}$ on which experimental results both for $\mathrm{M}$ and $\mathrm{MAl}$ are available $(\mathrm{M}=\mathrm{Fe}, \mathrm{Ni}, \mathrm{Cu})$, the interface is terminated by oxygen for pure $M$. Therefore, the termination for MAl should be either (C) or (D). Because (OonM) is

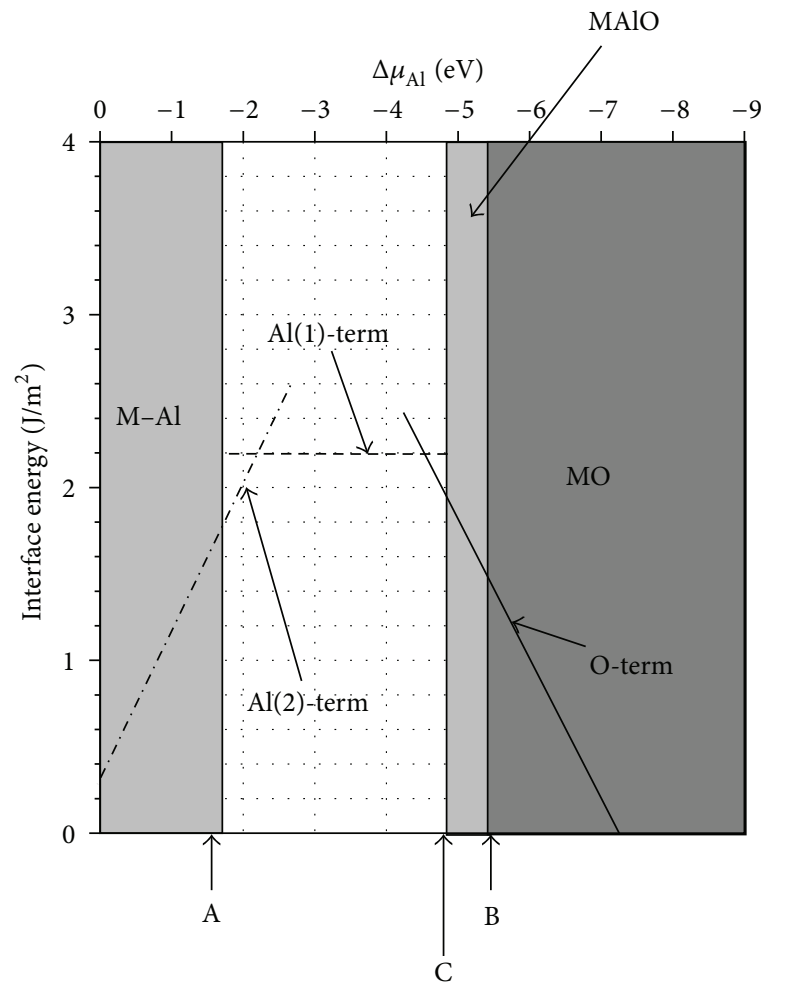

Figure 2: Schematic diagram of interface energy and preferred interface termination as a function of $\Delta \mu_{\mathrm{Al}}$ (chemical potential of $\mathrm{Al}$ ) for $\mathrm{M}$ with intermetallic compound (MAl) and oxides (MO) formation taken into account. On the left side of the border $\mathrm{A}, \mathrm{Al}_{2} \mathrm{O}_{3}$ reduces to $\mathrm{Al}$ metal. On the right side of the border $\mathrm{B}$, the interface is not $\mathrm{Al}_{2} \mathrm{O}_{3} / \mathrm{M}$ (pure metal) but $\mathrm{Al}_{2} \mathrm{O}_{3} / \mathrm{MO}_{x}$ (metal oxide). When $a_{\mathrm{Al}}$ is larger than that at the border $\mathrm{B}$, the interface is $\mathrm{O}$-terminated. If mixed oxide phase MAlO exists, the border $\mathrm{C}$ appears in the figure and the interface with alumina would be $\mathrm{Al}_{2} \mathrm{O}_{3} / \mathrm{MAlO}_{x}$ instead of $\mathrm{Al}_{2} \mathrm{O}_{3} / \mathrm{MO}_{x}$.

smaller than (OonAl), expression (d) or $\left(\mathrm{d}^{\prime}\right)$ applies. This means that our formula predicts Al-termination for $\mathrm{MAl}$ $(\mathrm{M}=\mathrm{Fe}, \mathrm{Ni}, \mathrm{Cu})$. The experimental results agree with this prediction. In Section 2.2 it is noted that switching $\mathrm{O}$-terminated interface with pure $\mathrm{M}$ to Al-termination by adding $\mathrm{Al}$ in $\mathrm{M}$ should be possible. Our experiments on alumina/Ni, $\mathrm{NiAl}, \mathrm{Cu}$, and $\mathrm{Cu}-9 \mathrm{Al}$ interfaces [10] actually demonstrated the above idea of termination switching. The experiment clearly showed that O-terminated interface with 
TABLE 5: The interface prediction for pure metal (M), examination of interface type and interface prediction for aluminum-containing alloy, and experimental results on interface termination in references.

\begin{tabular}{|c|c|c|c|c|c|}
\hline \multirow{2}{*}{ M } & \multirow{2}{*}{$\begin{array}{l}\text { Predicted interface termination } \\
\quad \text { for pure metal }(\mathrm{M})\end{array}$} & \multicolumn{2}{|c|}{ Predicted interface type for MAl } & \multirow{2}{*}{$\begin{array}{c}\text { Predicted interface } \\
\text { termination for alloy (MAl) }\end{array}$} & \multirow{2}{*}{$\begin{array}{l}\text { Experimental results } \\
\text { from references }\end{array}$} \\
\hline & & Approx-1 & Approx-2 & & \\
\hline $\mathrm{Si}$ & $\mathrm{O}$ & $\mathrm{C}$ & $\mathrm{C}$ & $\mathrm{O}$ & \\
\hline $\mathrm{Ti}$ & $\mathrm{O}$ & $\mathrm{C}$ & $\mathrm{C}$ & $\mathrm{O}$ & $\mathrm{Al}, \mathrm{O}$ \\
\hline V & $\mathrm{O}$ & $\mathrm{D}$ & $\mathrm{D}$ & $\mathrm{Al}$ & \\
\hline $\mathrm{Cr}$ & $\mathrm{O}$ & $\mathrm{D}$ & $\mathrm{D}$ & $\mathrm{Al}$ & \\
\hline $\mathrm{Fe}$ & $\mathrm{O}$ & $\mathrm{D}$ & $\mathrm{D}$ & $\mathrm{Al}$ & $\mathrm{Al}$ \\
\hline $\mathrm{CO}$ & $\mathrm{O}$ & $\mathrm{D}$ & $\mathrm{D}$ & $\mathrm{Al}$ & \\
\hline $\mathrm{Ni}$ & $\mathrm{O}$ & $\mathrm{D}$ & $\mathrm{D}$ & $\mathrm{Al}$ & $\mathrm{Al}$ \\
\hline $\mathrm{Cu}$ & $\mathrm{O}$ & $\mathrm{D}$ & $\mathrm{D}$ & $\mathrm{Al}$ & $\mathrm{Al}$ \\
\hline $\mathrm{Zn}$ & $\mathrm{O}$ & $\mathrm{D}$ & $\mathrm{D}$ & $\mathrm{Al}$ & \\
\hline Ga & $\mathrm{O}$ & $\mathrm{D}$ & $\mathrm{D}$ & $\mathrm{Al}$ & \\
\hline $\mathrm{Ge}$ & $\mathrm{O}$ & $\mathrm{D}$ & $\mathrm{D}$ & $\mathrm{Al}$ & \\
\hline $\mathrm{Zr}$ & $\mathrm{O}$ & $\mathrm{C}$ & $\mathrm{C}$ & $\mathrm{O}$ & \\
\hline $\mathrm{Nb}$ & $\mathrm{O}$ & $\mathrm{C}$ & $\mathrm{C}$ & $\mathrm{O}$ & \\
\hline Mo & $\mathrm{O}$ & $\mathrm{D}$ & $\mathrm{D}$ & $\mathrm{Al}$ & \\
\hline $\mathrm{Ru}$ & $\mathrm{Al}, \mathrm{O}$ & A & $\mathrm{D}$ & $\mathrm{Al}$ & \\
\hline $\mathrm{Rh}$ & $\mathrm{Al}, \mathrm{O}$ & A & $\mathrm{D}$ & $\mathrm{Al}$ & \\
\hline $\mathrm{Pd}$ & $\mathrm{Al}$ & A & A & $\mathrm{Al}$ & \\
\hline $\mathrm{Ag}$ & $\mathrm{Al}$ & A & A & $\mathrm{Al}$ & \\
\hline In & $\mathrm{O}$ & $\mathrm{D}$ & $\mathrm{D}$ & $\mathrm{Al}$ & \\
\hline Sn & $\mathrm{O}$ & $\mathrm{D}$ & $\mathrm{D}$ & $\mathrm{Al}$ & \\
\hline $\mathrm{La}$ & $\mathrm{O}$ & - & - & $\mathrm{Al}_{2} \mathrm{O}_{3}$ reduction & \\
\hline Hf & $\mathrm{O}$ & - & - & $\mathrm{Al}_{2} \mathrm{O}_{3}$ reduction & \\
\hline $\mathrm{Ta}$ & $\mathrm{O}$ & $\mathrm{C}$ & C & $\mathrm{O}$ & \\
\hline W & $\mathrm{O}$ & $\mathrm{C}$ & C & $\mathrm{O}$ & \\
\hline $\operatorname{Re}$ & $\mathrm{O}$ & $\mathrm{D}$ & $\mathrm{D}$ & $\mathrm{Al}$ & \\
\hline Os & $\mathrm{O}$ & $\mathrm{D}$ & $\mathrm{D}$ & $\mathrm{Al}$ & \\
\hline Ir & $\mathrm{Al}, \mathrm{O}$ & A & $\mathrm{D}$ & $\mathrm{Al}$ & \\
\hline Pt & $\mathrm{Al}, \mathrm{O}$ & A & $\mathrm{D}$ & $\mathrm{Al}$ & \\
\hline $\mathrm{Au}$ & $\mathrm{Al}$ & A & A & $\mathrm{Al}$ & \\
\hline $\mathrm{Hg}$ & $\mathrm{Al}, \mathrm{O}$ & A & $\mathrm{D}$ & $\mathrm{Al}$ & \\
\hline $\mathrm{Pb}$ & $\mathrm{O}$ & $\mathrm{D}$ & $\mathrm{D}$ & $\mathrm{Al}$ & \\
\hline $\mathrm{Bi}$ & $\mathrm{O}$ & $\mathrm{D}$ & $\mathrm{D}$ & $\mathrm{Al}$ & \\
\hline
\end{tabular}

pure $\mathrm{Ni}$ and pure $\mathrm{Cu}$ changed to $\mathrm{Al}$-terminated with $\mathrm{NiAl}$ and $\mathrm{Cu}-9 \mathrm{Al}$.

For $\mathrm{M}=\mathrm{Ti}$, where the expression (c) or $\left(\mathrm{c}^{\prime}\right)$ is satisfied, our formula predicts O-termination. In the experimental reports, both O-termination and Al-termination appear to be obtained depending on the conditions (oxygen potential) for the interface formation as discussed in Section 3.1. Altermination, which is in disagreement with the prediction, was obtained under low oxygen pressure at high temperature. Under such condition, adsorbed oxygen is known to dissolve into bulk $\mathrm{Ti}$ [36]. For $\mathrm{Ti}$, although $(\mathrm{OonAl})<(\mathrm{OonM})$, it appears that dissolution of oxygen at the interface into Ti occurs, resulting in Al-termination. The dissolution of oxygen into metal or alloy is highly dependent on a kind of metals or alloy and is not taken into account in the prediction formula. Among $\mathrm{Si}, \mathrm{Ti}, \mathrm{Zr}, \mathrm{Nb}$, Ta, and $\mathrm{W}$, which satisfy expression $(c)$ or $\left(c^{\prime}\right)$, similar behavior as for Ti is expected for $\mathrm{Zr}, \mathrm{Nb}$, and $\mathrm{Ta}$, because these three metals dissolve considerable amount of oxygen according to the phase diagrams.

One more thing to be noted is that all the metals that satisfy expression (c) or $\left(c^{\prime}\right)$ have a mixed oxide phase described as MAlO in Figure 2, $\mathrm{Al}_{2} \mathrm{O}_{3} \cdot \mathrm{SiO}_{2}, \mathrm{Al}_{2} \mathrm{O}_{3} \cdot \mathrm{TiO}_{2}, 2 \mathrm{Al}_{2} \mathrm{O}_{3}$ $\cdot \mathrm{ZrO}_{2}, \quad 1 / 2\left(\mathrm{Al}_{2} \mathrm{O}_{3} \cdot \mathrm{Nb}_{2} \mathrm{O}_{5}\right) \quad\left(=\mathrm{AlNbO}_{4}\right), \quad 1 / 2\left(\mathrm{Al}_{2} \mathrm{O}_{3} \cdot \mathrm{Ta}_{2} \mathrm{O}_{5}\right)$ $\left(=\mathrm{AlTaO}_{4}\right), 2 \mathrm{Al}_{2} \mathrm{O}_{3} \cdot 6 \mathrm{WO}_{3}\left(=\mathrm{Al}_{2}\left(\mathrm{WO}_{4}\right)_{3}\right)$.

As mentioned in Section 3.2, interface for these metals could be $\mathrm{Al}_{2} \mathrm{O}_{3} / \mathrm{MAlO}$ (border $\mathrm{C}$ in Figure 2), which contains $\mathrm{Al}-\mathrm{O}-\mathrm{M}-\mathrm{O}-$ bonding at the interface and hence is regarded 


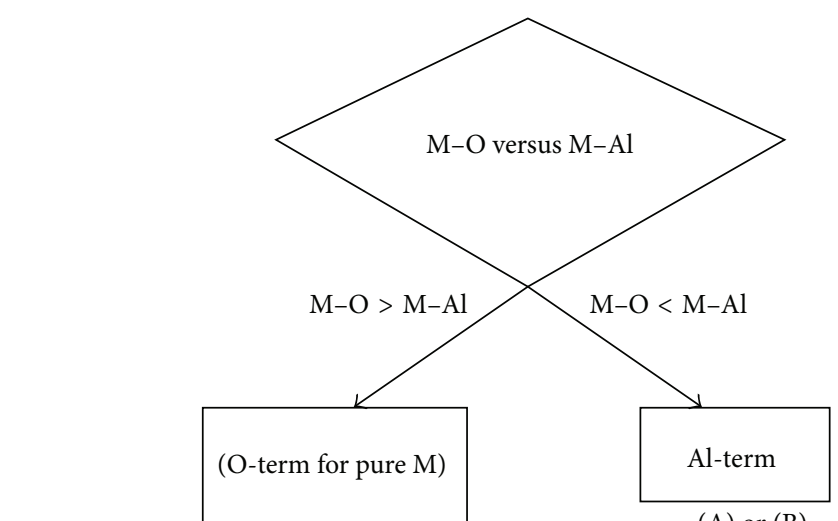

(A) or (B)

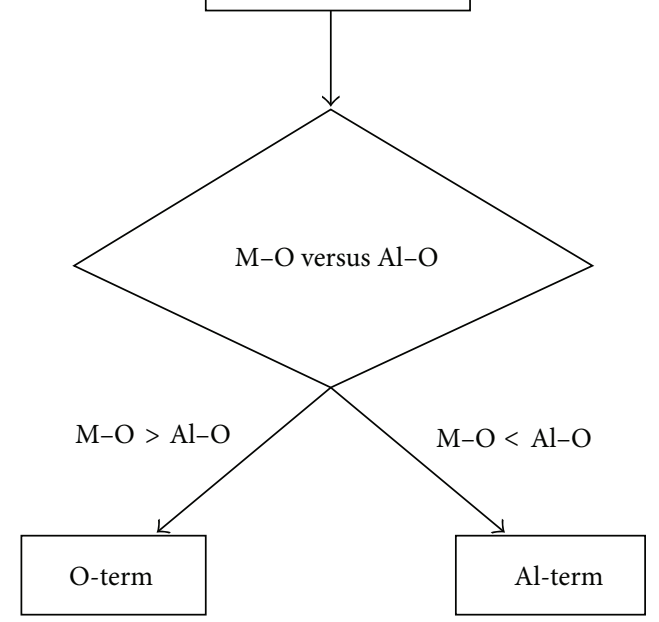

(C)

(D)

FIGURE 3: Flow chart for predicting a termination type among (A) (D) in the text.

as O-termination in this paper. When the formation enthalpy of metal oxide increases, approaching that of alumina, the position of borders B and C shifts toward left side in Figure 2, while the position of border $\mathrm{A}$ is not influenced by oxide formation enthalpy but mainly by the strength of $\mathrm{M}-\mathrm{Al}$ bonding (if the $\mathrm{M}-\mathrm{Al}$ bonding is stronger, the position of border $\mathrm{A}$ moves toward right side).

The features shown in Figure 2 in the theoretical study are based on thermodynamics and are common among all the systems calculated. Therefore, we can expect the features to be universal for any metal. Then, when the interface is Alterminated, alumina is expected to be in equilibrium with aluminum-containing alloys or intermetallics under oxygen partial pressure that metal is not oxidized. This guides the practically useful technique to switch interface bonding from an originally $\mathrm{O}$-terminated interface to Al-termination by adding $\mathrm{Al}$ in a metal $\mathrm{M}$. The exception of the application of this technique is the case where (OonAl) $<$ (OonM) (expression (c) or $\left(c^{\prime}\right)$ is satisfied). Interface bonding for metals that satisfy expression $(c)$ or $\left(c^{\prime}\right)$ would be processdependent in practice, because the thermodynamic stability of Al-terminated and O-terminated interface is very close for metals that satisfy both (OonAl) $<($ OonM $)$ and (formation enthalpy of oxide of metal $\mathrm{M}$ ) $<$ (formation enthalpy of
$\mathrm{Al}_{2} \mathrm{O}_{3}$ ). For such case, prediction is possible by observing which one of metal elements is preferentially oxidized in $\mathrm{Al}$-containing alloys or intermetallics. If $\mathrm{Al}$ is preferentially oxidized, the interface would be Al-terminated, whereas the preferential oxidation of $\mathrm{M}$ would results in $\mathrm{O}$-terminated.

It should be noted that if $\mathrm{MO}$ is more stable than $\mathrm{Al}_{2} \mathrm{O}_{3}$, interface $\mathrm{Al} / \mathrm{MO}$ instead of $\mathrm{Al}_{2} \mathrm{O}_{3} / \mathrm{M}$ should be formed under thermodynamic equilibrium. Among metals we consider in Table 2, Mg, La, and Hf correspond to the case.

By incorporating the discussion on Figure 2 into the expressions presented here, we can make an algorithm to find interface termination in Al-containing alloy as in Figure 3. This algorithm guides a novel method to control interface termination; for a metal with (OonM) $<$ (OonAl), an interface that exhibits $\mathrm{O}$-termination in pure metal can be switched to Al-termination by alloying the metal with Al. It also concludes that a stable Al-terminated interface cannot be formed for metals with $($ OonM $)>($ OonAl) under equilibrium conditions if oxygen partial pressure is not low enough to reduce $\mathrm{Al}_{2} \mathrm{O}_{3}$. Therefore, for such metals, utilizing a quenching process is necessary to obtain Al-terminated interfaces. One example of a quenching process is depositing $\mathrm{Al}$ on metals followed by oxidation without sufficient annealing, which avoids atomic diffusion needed to reach thermodynamically stable O-termination.

The influence of oxygen partial pressure is not taken into account in (1) and (3), which are used to calculate the adsorption energies of $\mathrm{Al}$ on $\mathrm{M}$ and oxygen on $\mathrm{M}$, respectively. On the other hand, the strengths of $\mathrm{M}-\mathrm{O}$ and $\mathrm{Al}-\mathrm{O}$ bonds should depend on the oxygen partial pressure. Therefore, prediction by this method is not accurate, especially for easily reduced metals. However, it provides a guide for termination, which we believe is quite useful for material development.

\section{Conclusions}

Interface bonding between alumina and aluminum-containing alloy (MAl) has been investigated. A method to predict an interface terminating species is proposed by extending the prediction method already proposed for the interface between alumina and pure metals. In the method, to find the most stable interface termination, the interface bonding energies of differently terminated interfaces, which are estimated using the adsorption energy of $\mathrm{Al}$ on base-metal $\mathrm{M}$ and that of $\mathrm{M}$ on $\mathrm{M}$, and the adsorption energy of oxygen on $\mathrm{M}$ and $\mathrm{Al}$ are compared. In the algorithm for prediction, interface termination at alumina-pure metal interface should be first examined. Then, if the interface with pure metal is Al-terminated, values of (AlonM) and (AlonAl) are compared. For O-terminated interface with pure metal, values of (OonM) and (OonAl) should be compared. This procedure gives the type of interface bonding in aluminum-containing alloy according to the expressions $(\mathrm{a})-(\mathrm{d})$ or $\left(\mathrm{a}^{\prime}\right)-\left(\mathrm{d}^{\prime}\right)$ in the text. Based on the algorithm, it is also revealed that O-terminated interface can be switched to Al-terminated one by adding $\mathrm{Al}$ to pure metal $\mathrm{M}$.

The predicted results are compared with those deduced from experimental studies. The agreement is very good. For aluminum-containing alloys where there is little difference 
between (OonM) and (OonAl), termination type would be dependent on temperature and oxygen partial pressure and these influences should be taken into account for more accurate and precise prediction. However, for most of metals, the formula for prediction proposed here should be very effective and useful for material screening in developing interfaces because the method is based on thermodynamics and uses only basic parameters of metals and oxides.

\section{Conflict of Interests}

The authors declare that there is no conflict of interests regarding the publication of this paper.

\section{Acknowledgments}

Michiko Yoshitake greatly appreciates partial support by Grants-in-Aid for Scientific Research from the Japan Society for the Promotion of Science (no. 20560027) and from The Mitsubishi Foundation.

\section{References}

[1] U. Alber, H. Müllejans, and M. Rühle, "Wetting of copper on $\alpha$ $\mathrm{Al}_{2} \mathrm{O}_{3}$ surfaces depending on the orientation and oxygen partial pressure," Micron, vol. 30, no. 2, pp. 101-108, 1999.

[2] V. Merlin and N. Eustathopoulos, "Wetting and adhesion of $\mathrm{Ni}-\mathrm{Al}$ alloys on $\alpha-\mathrm{Al}_{2} \mathrm{O}_{3}$ single crystals," Journal of Materials Science, vol. 30, no. 14, pp. 3619-3624, 1995.

[3] D. Chatain, F. Chabert, V. Ghetta, and J. Fouletier, "New experimental setup for wettability characterization under monitored oxygen activity: II, wettability of sapphire by silver-oxygen melts," Journal of the American Ceramic Society, vol. 77, no. 1, pp. 197-201, 1994.

[4] S. Shi, S. Tanaka, and M. Kohyama, "First-principles study of the tensile strength and failure of $\alpha-\mathrm{Al}_{2} \mathrm{O}_{3}(0001) / \mathrm{Ni}(111)$ interfaces," Physical Review B, vol. 76, Article ID 075431, 2007.

[5] S. Shi, S. Tanaka, and M. Kohyama, "First-principles investigation of the atomic and electronic structures of $\alpha-\mathrm{Al}_{2} \mathrm{O}_{3}(0001) /$ $\mathrm{Ni}(111)$ Interfaces," Journal of the American Ceramic Society, vol. 90, no. 8, pp. 2429-2440, 2007.

[6] S. Shi, S. Tanaka, and M. Kohyama, "Influence of interface structure on Schottky barrier heights of $\alpha-\mathrm{Al}_{2} \mathrm{O}_{3}(0001) / \mathrm{Ni}(111)$ interfaces: a first-principles study," Materials Transactions, vol. 47, no. 11, pp. 2696-2700, 2006.

[7] K. Shiraishi, T. Nakayama, T. Nakaoka, A. Ohta, and S. Miyazaki, "Theoretical investigation of metal/dielectric interfaces? Breakdown of Schottky barrier limits?" ECS Transactions, vol. 13, no. 2, pp. 21-27, 2008.

[8] T. Nagata, P. Ahmet, Y. Z. Yoo et al., "Schottky metal library for ZNO-based UV photodiode fabricated by the combinatorial ion beam-assisted deposition," Applied Surface Science, vol. 252, no. 7, pp. 2503-2506, 2006.

[9] A. Asthagiri, C. Niederberger, A. J. Francis, L. M. Porter, P. A. Salvador, and D. S. Sholl, "Thin Pt films on the polar $\mathrm{SrTiO}_{3}(1$ 1 1) surface: an experimental and theoretical study," Surface Science, vol. 537, no. 1-3, pp. 134-152, 2003.

[10] M. Yoshitake, S. Nemšák, T. Skála et al., "Modification of terminating species and band alignment at the interface between alumina films and metal single crystals," Surface Science, vol. 604, no. 23-24, pp. 2150-2156, 2010.

[11] M. Yoshitake, S. Yagyu, and T. Chikyow, "Novel method for the prediction of an interface bonding species at alumina/metal interfaces," Journal of Vacuum Science and Technology A, vol. 32, no. 2, Article ID 021102, 8 pages, 2014.

[12] http://interchembond.nims.go.jp/.

[13] A. R. Miedema and J. W. F. Dorleijn, "Quantitative predictions of the heat of adsorption of metals on metallic substrates," Surface Science, vol. 95, no. 2-3, pp. 447-464, 1980.

[14] M. Yoshitake, Y.-R. Aparna, and K. Yoshihara, "General rule for predicting surface segregation of substrate metal on film surface," Journal of Vacuum Science \& Technology A, vol. 19, no. 4, pp. 1432-1437, 2001.

[15] http://surfseg.nims.go.jp/SurfSeg/menu.html.

[16] K. Tanaka and K. Tamaru, "A general rule in chemisorption of gases on metals," Journal of Catalysis, vol. 2, no. 5, pp. 366-370, 1963.

[17] D. Brennan, D. O. Hayward, and B. M. Trapnell, "The calorimetric determination of the heats of adsorption of oxygen on evaporated metal films," Proceedings of the Royal Society of London A, vol. 256, pp. 81-105, 1960.

[18] N. A. Lange, Handbook of Chemistry, McGraw-Hill, 1956.

[19] L. Brewer, "The thermodynamic properties of the oxides and their vaporization processes," Chemical Reviews, vol. 52, no. 1, pp. 1-75, 1953.

[20] D. R. Lide, Ed., CRC Handbook of Chemistry and Physics, CRC Press, 74th edition, 1993-1994.

[21] P. Brix and G. Herzberg, "Fine structure of the SchumannRunge bands near the convergence limit and the dissociation energy of the oxygen molecule," Canadian Journal of Physics, vol. 32, pp. 110-135, 1954.

[22] R. M. Jaeger, H. Kuhlenbeck, H.-J. Freund et al., "Formation of a well-ordered aluminium oxide overlayer by oxidation of NiAl(110)," Surface Science, vol. 259, no. 3, pp. 235-252, 1991.

[23] G. Kresse, M. Schmid, E. Napetschnig, M. Shishkin, L. Köhler, and P. Varga, "Materials science: structure of the ultrathin aluminum oxide film on $\mathrm{NiAl}(110)$," Science, vol. 308, no. 5727, pp. 1440-1442, 2005.

[24] M. Yoshitake, W. Song, J. Libra et al., "Interface termination and band alignment of epitaxially grown alumina films on $\mathrm{Cu}$ Al alloy," Journal of Applied Physics, vol. 103, Article ID 033707, 2008.

[25] V. Maurice, G. Despert, S. Zanna, P. Josso, M.-P. Bacos, and P. Marcus, "The growth of protective ultra-thin alumina layers on $\gamma$-TiAl(1 111$)$ intermetallic single-crystal surfaces," Surface Science, vol. 596, no. 1-3, pp. 61-73, 2005.

[26] V. Maurice, G. Despert, S. Zanna, P. Josso, M.-P. Bacos, and P. Marcus, "XPS study of the initial stages of oxidation of $\alpha_{2}-\mathrm{Ti}_{3} \mathrm{Al}$ and $\gamma$-TiAl intermetallic alloys," Acta Materialia, vol. 55, no. 10, pp. 3315-3325, 2007.

[27] K. Kovács, I. V. Perczel, V. K. Josepovits, G. Kiss, F. Réti, and P. Deák, "In situ surface analytical investigation of the thermal oxidation of Ti-Al intermetallics up to $1000^{\circ} \mathrm{C}$," Applied Surface Science, vol. 200, no. 1-4, pp. 185-195, 2002.

[28] M. Schmiedgen, P. C. J. Graat, B. Baretzky, and E. J. Mittemeijer, "The initial stages of oxidation of $\gamma$-TiAl: an X-ray photoelectron study," Thin Solid Films, vol. 415, no. 1-2, pp. 114-122, 2002.

[29] J. F. Silvain, J. E. Barbier, Y. Lepetitcorps, M. Alnot, and J. J. Ehrhardt, "Chemical and structural analysis of TiAl thin films 
sputter deposited on carbon substrates," Surface and Coatings Technology, vol. 61, no. 1-3, pp. 245-250, 1993.

[30] J. Xia, H. Dong, and T. Bell, "Surface properties of a $\gamma$-based titanium aluminide at elevated temperatures," Intermetallics, vol. 10, no. 7, pp. 723-729, 2002.

[31] H. Graupner, L. Hammer, K. Heinz, and D. M. Zehner, "Oxidation of low-index FeAl surfaces," Surface Science, vol. 380, no. 2-3, pp. 335-351, 1997.

[32] E. Loginova, F. Cosandey, and T. E. Madey, "Nanoscopic nickel aluminate spinel $\left(\mathrm{NiAl}_{2} \mathrm{O}_{4}\right)$ formation during $\mathrm{NiAl}\left(\begin{array}{ll}1 & 1\end{array}\right)$ oxidation," Surface Science, vol. 601, no. 3, pp. L11-L14, 2007.

[33] W. Zhang, J. R. Smith, and A. G. Evans, "The connection between $\mathrm{ab}$ initio calculations and interface adhesion measurements on metal/oxide systems: $\mathrm{Ni} / \mathrm{Al}_{2} \mathrm{O}_{3}$ and $\mathrm{Cu} / \mathrm{Al}_{2} \mathrm{O}_{3}$," Acta Materialia, vol. 50, no. 15, pp. 3803-3816, 2002.

[34] W. Zhang and J. R. Smith, "Nonstoichiometric interfaces and $\mathrm{Al}_{2} \mathrm{O}_{3}$ adhesion with $\mathrm{Al}$ and Ag," Physical Review Letters, vol. 85, no. 15, pp. 3225-3228, 2000.

[35] J. Feng, W. Zhang, and W. Jiang, "Ab initio study of $\mathrm{Ag} / \mathrm{Al}_{2} \mathrm{O}_{3}$ and $\mathrm{Au} / \mathrm{Al}_{2} \mathrm{O}_{3}$ interfaces," Physical Review $\mathrm{B}$, vol. 72 , no. 11, Article ID 115423, 11 pages, 2005.

[36] M. Yoshitake and K. Yoshihara, "The surface segregation of Ti$\mathrm{Nb}$ composite film and its application to a smart getter material," Vacuum, vol. 51, no. 3, pp. 369-376, 1998. 

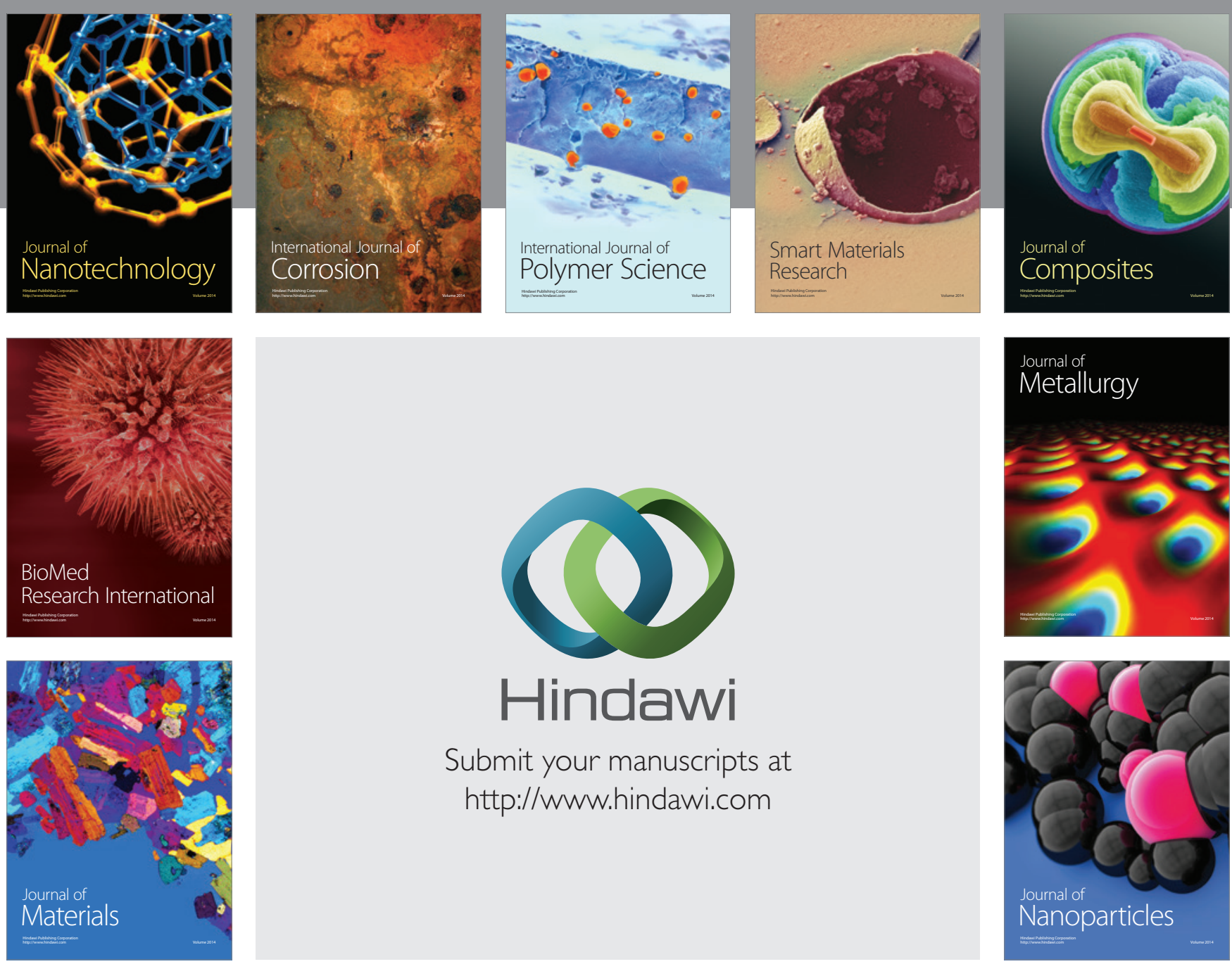

Submit your manuscripts at http://www.hindawi.com
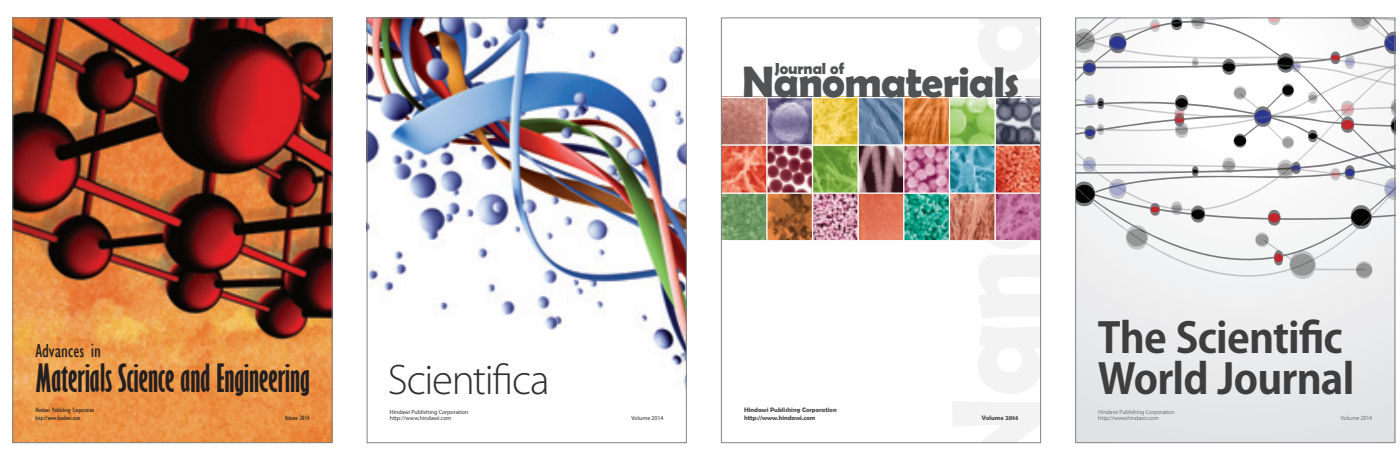

\section{The Scientific World Journal}
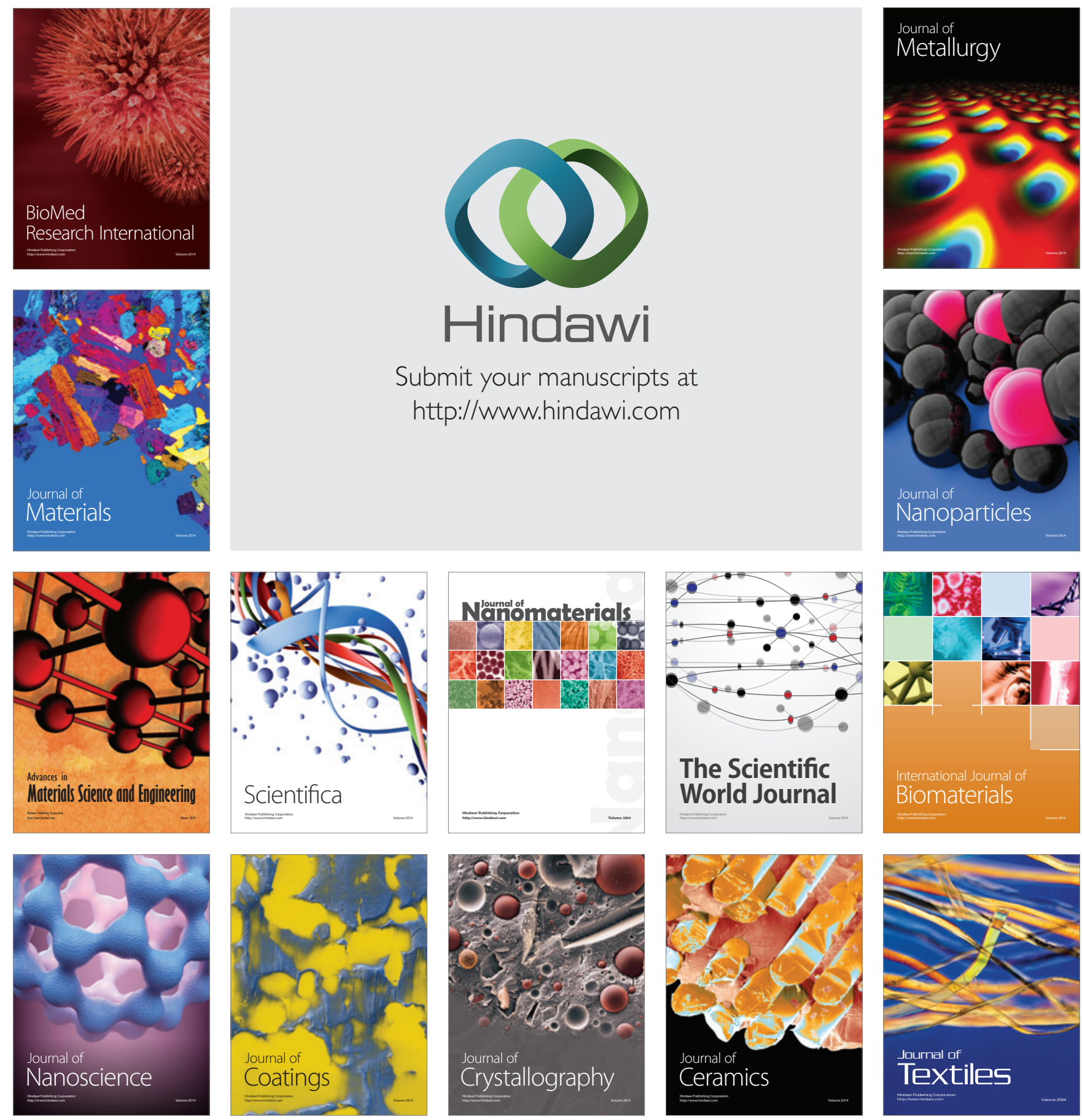